\title{
The Luster of Chrome: Nixon, Rhodesia, and the Defiance of UN Sanctions
}

\author{
Eddie Michel
}

Department of Historical and Heritage Studies, University of Pretoria, Pretoria, South Africa

\begin{abstract}
My article discusses the tilt towards the white minority regimes of southern Africa, specifically Rhodesia that occurred during the Nixon era. The White House approach was shaped by anti-communism and economic interest combined with an apathy for the cause of black liberation. This led to a blatant disregard of the principle of majority rule and open violation of UN sanctions. Furthermore, as Nixon's actions regarding southern Africa were reflective of core beliefs within the White House of how to approach international politics, Rhodesia provides an illuminative lens regarding the broader imperatives that guided the Nixonian approach to global relations.
\end{abstract}

On November 17, 1971, President Richard Nixon signed the Military Procurement Act, which under Section 503, known as the Byrd Amendment, authorized the importation into the United States of any "strategic and critical" metal-bearing ore from a free world country as long as the importation of the same ore from a communist country was not prohibited by law. The wording was deliberately formulated to allow U.S. corporations access to the mineral wealth of Rhodesia, an action that placed Washington in open violation of United Nations (UN) sanctions. The White House decision to defy the global community was based on geopolitical strategy and economic interest but was further reinforced by Nixon's apathy toward the cause of black liberation in southern Africa. ${ }^{1}$

\footnotetext{
${ }^{1}$ Memorandum for the President from Secretary of State William P. Rogers, Statement on the Provision of Military Procurement Authorization Bill Permitting the Import of Rhodesian Chrome, November 16, 1971, National Security Council (hereafter NSC) Institutional (“H”) Files, National Security Study Memorandum (hereafter NSSM) 142, box H-188, Richard Nixon Presidential Library and Museum, Yorba Linda, California (hereafter RNPL); Memorandum for the President from Henry A. Kissinger, Statement to be made on the signing of the Military Procurement Authorization Bill, November 16, 1971, NSC Country Files, Rhodesia vol.
} 
An analysis of U.S. relations with Rhodesia during the Nixon years allows us a better grasp and understanding of the pressure points which shaped the White House approach to foreign relations over this era. Indeed, Salisbury provides a particularly useful illuminative lens given that the Rhodesian question encapsulated key political issues of the 1970s including the Cold War, human rights and race relations. Furthermore, as part of the global 'periphery', Rhodesia offered a great deal of flexibility to the White House in shaping policy. This allowed the Nixon administration to adopt an approach that truly reflected the core beliefs within the White House regarding international politics.

As clearly demonstrated by its policies towards Salisbury, the Nixon White House viewed anti-communism, economic interest and the need for strategic minerals as the key dynamics in policy decision making. Nixon was also not immune to racial prejudices and held close ties with Southern political figures who supported white Rhodesia on racial grounds.

The existing historiography offers a variety of arguments that purport to explain U.S. foreign relations with Africa and the Third World during the 1960s and 1970s. A number of historians, notably Odd Arne Westad and John Lewis Gaddis, have argued that the "containment" of global Communism was the principal concern of policymakers during the entire Cold War era. Indeed, scholars have suggested that the wider Third World was integral to the broader struggle for supremacy as both Washington and Moscow realized that full scale conflict in Europe or North America was unwinnable, and therefore the Cold War 
descended into a contest that according to Nancy Mitchell consisted of "shadow-boxing in the periphery.",2

Some scholars have observed that U.S. aid was primarily restricted to regimes that displayed anti-communist credentials, opposed radicalism, and were willing to act as regional policemen in defense of Western interests. Policymakers in Washington generally exhibited little concern if such allies displayed repressive internal policies provided the governments remained firmly in the U.S. sphere of influence. Indeed, historians have argued that the white minority regimes in southern Africa deliberately employed Cold War rhetoric to obtain U.S. aid. $^{3}$

\footnotetext{
${ }^{2}$ Quotation from Nancy Mitchell, “Terrorists or Freedom Fighters? Jimmy Carter and Rhodesia," in Cold War in Southern Africa: White Power, Black Liberation, ed. Sue Onslow (London, 2012), 178; John Lewis Gaddis, Strategies of Containment: A Critical Appraisal of American National Security Policy during the Cold War (Oxford, 2005), ix, 20-22, 127-28, 200-2, 273-75, and 343-45; Nancy Mitchell "The Cold War and Jimmy Carter," in The Cambridge History of the Cold War, Volume III, Endings, ed. Melvyn P. Leffler and Odd Arne Westad (Cambridge, 2011), 67, 74-75; Elizabeth Schmidt, Foreign Intervention in Africa: From the Cold War to the War on Terror (Cambridge, 2013), 1-2 and 7-8; Odd Arne Westad, The Global Cold War (Cambridge, 2007), 34-35, 38, and 111.

${ }^{3}$ Andrew DeRoche, Black, White and Chrome: The United States and Zimbabwe, 1953-1998 (Trenton, NJ, 2001), 7 and 209-10; Gerald Horne, From the Barrel of a Gun: The United States and the War against Zimbabwe (Chapel Hill, NC, 2001), 166; Mark Atwood Lawrence, “Containing Globalism: The United States and the Developing World in the 1970s," in The Shock of the Global: The 1970s in Perspective, ed. Niall Ferguson et al. (Cambridge, MA, 2010), 209-10; Robert Litwak, Détente and the Nixon Doctrine: American Foreign Policy and the Pursuit of Stability, 1969-1976 (Cambridge, 1986); Jeremi Suri, "Henry Kissinger and the Geopolitics of Globalization," in The Shock of the Global, ed. Ferguson et al., 175-86; Michael E. Latham, “The Cold War in the Third World, 1963-1975," in The Cambridge History of the Cold War, Volume II, Crisis and Détente, ed. Melvin P. Leffler and Odd Arne Westad (Cambridge, 2010), 259-63; Chris Saunders and Sue Onslow, "The Cold War and Southern Africa, 1976-1990," The Cambridge History of the Cold War, Volume
} 
A number of scholars have noted the role of economics in shaping policy toward Africa during this period. According to this school of thought, the promotion of free market capitalism, specifically access to raw materials and markets, was the principal objective of policymakers. The mineral wealth, industrialized economies, and cheap labor costs of the Rhodesian and South African regimes proved to be especially alluring for corporate investment and trade. ${ }^{4}$

Historians have further posited that for the U.S. government the ideological struggle of capitalism versus Soviet collectivism heightened the importance of trade with and investment in Africa and the wider Third World. Westad has asserted that Washington sought a greater economic predominance globally in order to demonstrate the superiority of the free market system over the rigid state-centric economy of the USSR. ${ }^{5}$

The scholarship has also considered the importance of an emerging human rights movement in the 1970s on the development of U.S. foreign policy. Indeed, the growing assertiveness of the human rights movement and the increasing influence of the moral

III, ed. Leffler and Westad, 223; Westad, The Global Cold War, 34-35; Schmidt, Foreign Intervention in Africa, $8,81-88$, and 103 .

${ }^{4}$ Thomas Borstelmann, Apartheid's Reluctant Uncle: The United States and Southern Africa in the Early Cold War (Oxford, 1993), 81, 97; R. Hunt Davis, Jr., “US Policy toward South Africa: A Dissenting View," in American Policy in Southern Africa: The Stakes and the Stance, 2nd ed., ed. René Lemarchand (Washington, D.C., 1981), 323-26; William Foltz, “U.S. Policy toward Southern Africa: Economic and Strategic Constraints," in American Policy in Southern Africa, ed. Lemarchand, 283-85; David N. Gibbs, The Political Economy of Third World Intervention: Mines, Money, and U.S. Policy in the Congo Crisis (Chicago, IL, 1991); Edgar Lockwood, "The Case of Zimbabwe," in American Policy in Southern Africa, ed. Lemarchand, 169; Robert K. Massie, Loosing the Bonds: The United States and South Africa in the Apartheid Years (New York, 1997); Winston Nagan, “The U.S. and South Africa: The Limits of "Peaceful Change," in American Policy in Southern Africa, ed. Lemarchand, 231; Westad, The Global Cold War, 208.

${ }^{5}$ Westad, The Global Cold War, 30-32. 
ideology of human rights have been highlighted as a major factor in decision-making. It has been widely agreed that during the Jimmy Carter years a priority for the president, as observed by Michael Cotey Morgan was "to launch a new era in American foreign policy by attaching central importance to human rights as a standard for crafting U.S. decisions."

Historians have discussed the impact of race, specifically the rise of AfricanAmerican political power during the Cold War era, on foreign policy toward Africa. They have posited that as early as the 1950s, African Americans considered the "liberation" of colonial peoples of color inseparable from the struggle for racial justice in the United States. They have further argued that the occupants of the Oval Office, especially by the 1970s, were not only aware of the growing importance of the African-American vote but also that the Rhodesian issue represented a test of the White House's stance on racial issues. ${ }^{7}$

Gerald Horne has offered a different perspective on the impact of race by suggesting that during the Lyndon B. Johnson years the United States' primary aim regarding southern

\footnotetext{
${ }^{6}$ Quotation from Michael Cotey Morgan, "The Seventies and the Rebirth of Human Rights," in The Shock of the Global, ed. Ferguson et al., 238; DeRoche, Black, White and Chrome, 209-10, 228; Paul Gordon Lauren, Power and Prejudice: The Politics and Diplomacy of Racial Discrimination (Boulder, CO, 1996), 266-68; Lawrence, “Containing Globalism,” 214, 216; William Minter, King Solomon's Mines Revisited: Western Interests and the Burdened History of Southern Africa (New York, 1986), 298-99; Mitchell, “Terrorists or Freedom Fighters?” 178, 189-191; Samuel Moyn, The Last Utopia: Human Rights in History, (Cambridge, MA, 2010), 118; Carl Watts, “"Dropping the F-bomb’: President Ford, the Rhodesian Crisis, and the 1976 Election," Panel 89: Domestic Aspects of U.S. Policy toward Southern Africa from Ford to Reagan, SHAFR Conference, Lexington, Kentucky, 2014.

${ }^{7}$ DeRoche, Black, White and Chrome, 4, 106, 115, 244-45; Andrew DeRoche, "Relations with Africa since 1900," in A Companion to American Foreign Relations, ed. Robert D. Schulzinger (Malden, MA, 2006), 117; Schmidt, Foreign Intervention in Africa, 24; Brenda Plummer, Rising Wind: Black Americans and U.S. Foreign Affairs, 1935-1960 (Chapel Hill, NC, 1996); Penny Von Eschen, Race Against Empire: Black Americans and Anticolonialism, 1937-1957 (Ithaca, NY, 1997).
} 
Africa was to avoid a race-based conflict that would aggravate racial tensions in the U.S. itself. In the case of the Nixon Administration, he posited that the White House adopted a dual electoral "Southern Strategy" and "Southern Africa Strategy" designed to gain white political support by slowing down the pace of racial change in both the southern states and southern Africa. He further suggests that the two strategies were mutually compatible as their origins lay in Cold War rationalization, which postulated African Americans and Africans as the allies or dupes of the communists. ${ }^{8}$

While the question of Rhodesia has been considered in the broader literature of U.S. foreign relations during the Sixties and Seventies, there is a comparative paucity of research regarding direct bilateral relations with Rhodesia especially in terms of examining policy toward Salisbury through the lens of the specific presidential administrations. Rhodesia is typically included as part of a wider history of policy decision-making.

A second issue is that the literature that does examine bilateral relations with Salisbury is simply too expansive to offer an in-depth analysis of each individual presidency and the rationale behind the presidential strategies to the Rhodesian crisis. Andrew DeRoche's book offers an overview of U.S. relations with Rhodesia/Zimbabwe between 1953 and 1998 but does not exclusively focus on the Unilateral Declaration of Independence (UDI) era and the inherent challenges that the rebellion posed for the United States both domestically and internationally. Carl Peter Watts provides an insightful analysis of the global responses to UDI. His book, however, is primarily an international history that covers the British, Commonwealth, and UN reactions as well as the U.S. approach in the immediate aftermath of the rebellion. ${ }^{9}$

\footnotetext{
${ }^{8}$ Horne, From the Barrel of a Gun, 7.

${ }^{9}$ DeRoche, Black, White and Chrome and Carl Peter Watts, Rhodesia's Unilateral Declaration of Independence: An International History, (New York, 2012).
} 
Another weakness in the existing scholarship is that much of the literature seeks to examine the Rhodesian issue primarily through the prism of race or it simply operates from the premise that the White House was clearly erroneous in not exerting greater pressure to advance the advent of majority rule. Such a restricted lens almost inevitably colors the interpretation of the source base. The fact that UDI sought to preserve white minority control has led some of the literature, even with hindsight, to operate from the standpoint that any U.S. actions that did not immediately advance the advent of majority rule were inherently wrong and fail to consider the diverse range of factors that influenced foreign policy during the Sixties and Seventies. ${ }^{10}$

A better approach considers both the global and domestic factors that shaped Nixon's policies towards Salisbury. Rhodesia as part of the global "periphery" allowed a great deal more flexibility in policy options than the main arenas of confrontation, and this is reflected in the differing approaches of the presidential administrations throughout the UDI era.

\section{Background}

Rhodesia, now known as Zimbabwe, was a self-governing British colony in southern Africa that in November 1965 defied London and unilaterally declared itself an independent nation. The Rhodesian government, controlled by the white minority, argued that it had rebelled in order to avoid the fate of many newly emergent African states, which had upon independence descended into one party dictatorships or spiraled into vicious ethnic conflicts. White Rhodesians were also vehemently anti-communist and the populist Rhodesian Front (RF) government held to a Manichean vision in which Rhodesia was a bastion of Western

\footnotetext{
${ }^{10}$ DeRoche, Black White and Chrome, 2-7; Horne, From the Barrel of a Gun, 4 and 12 and Lake, The "Tar Bay" Option, 1-5 and 277-279.
} 
Christian civilization under siege from the insidious forces of global communism that were spreading throughout Africa. ${ }^{11}$

It is also clear, however, that UDI also represented the determination of the white community to retain its power and privilege in an "independent" Rhodesia. White Rhodesians, having built an economically viable modern nation, benefited, for the most part, from a privileged existence paying little tax and enjoying a high quality of life. In the fall of 1965, Time magazine commented that, "Few communities in the world can match the sundrenched affluence that Rhodesia's hardy settlers have achieved for themselves." It was also increasingly obvious that the white Rhodesians had no intention of giving it away. The Rhodesian Prime Minister himself, Ian Smith, privately stated that "The white man is the master of Rhodesia ... He has built it and intends to keep it." ${ }^{, 12}$

The Rhodesian decision to go it alone met with condemnation and hostility from London. The British Prime Minister, Harold Wilson, decried UDI as "the action of a group of small and frightened men" and his government passed a series of increasingly stringent trade sanctions against Salisbury. ${ }^{13}$

\footnotetext{
${ }^{11}$ From Salisbury to Commonwealth Relations Office, no. 1707, November 11, 1965, PREM 13/545, The National Archives of the UK (hereafter TNA); From Salisbury to Commonwealth Relations Office, no. 1708, November 11, 1965, PREM 13/545, TNA; Donal Lowry, “The Impact of Anti-Communism on White Rhodesian Political Culture, c.1920s-1980," in Cold War in Southern Africa: White Power, Black Liberation, ed. Onslow, 90; Ian Smith, Bitter Harvest: Zimbabwe and the Aftermath of its Independence: The Memoirs of Africa's Most Controversial Leader (London, 2008), 107-8; Watts, Rhodesia's Unilateral Declaration of Independence, 39 .

12 “We Want Our Country,” Time Magazine, November 5, 1965, 40-48; Robert C. Good, UDI: The International Politics of the Rhodesian Rebellion (Princeton, NJ, 1973), 4.

${ }^{13}$ Speech of Prime Minister Harold Wilson to the House of Commons, November 11, 1965, PREM 13/545, TNA; Text of a Broadcast by the Prime Minister Harold Wilson, November 11, 1965, PREM 13/545, TNA; Foreign Affairs and Commonwealth Relations Office to Certain Missions, November 11, 1965, PREM 13/566,
} 
The United Nations also condemned the Rhodesian action and called on all states to refuse to recognize or render any assistance to the illegal regime. In December 1966, following a breakdown of talks between the British and Rhodesians, the UN Security Council (UNSC) imposed selective mandatory economic sanctions on Salisbury. The trade embargo listed several key Rhodesian export commodities, notably chrome. Seventeen months later, in May 1968, the UNSC unanimously adopted comprehensive mandatory sanctions on the pariah regime. ${ }^{14}$

In Washington, President Lyndon B. Johnson, embroiled in the escalating conflict in Vietnam and focused on his domestic Great Society legislation, considered UDI to be an unwelcome crisis that stemmed from the legacy of British colonialism. The importance of the “special relationship" between London and Washington, Johnson's own deeply held personal TNA; Southern Rhodesia Act 1965, November 16, 1965, PREM 13/545, TNA; Orders in Council made by Privy Council, November 16, 1965, PREM 13/545, TNA; From Foreign Office to All Her Majesty’s Representatives and from Commonwealth Relations Office to British High Commissions, December 1, 1965, PREM 13/1143, TNA; Good, UDI, 65, 69.

${ }^{14}$ United Kingdom Mission to the United Nations to Foreign Office, November 11, 1965, PREM 13/1113, TNA; From United Kingdom Mission to the United Nations, New York, November 13, 1965, PREM 13/545, TNA; Memorandum to Acting Secretary of State Ball from Director of Intelligence and Research Thomas L. Hughes, UDI Developments and Reactions, November 16, 1965, "Rhodesia, vol. 1 (3 of 3)," Country File, National Security Files (hereafter NSF), box 97, Lyndon Baines Johnson Presidential Library and Museum, Austin, Texas (hereafter LBJL); Memorandum of Telephone Conversation between Special Assistant for National Security Affairs Bundy and Under Secretary of State Ball, November 13, 1965, Foreign Relations of the United States (hereafter FRUS), 1964-1968, vol. XXIV, Africa, eds. Nina Davis Howland and David S. Patterson (Washington, DC, 1999), doc. 495; Resolution Adopted by the Security Council, Question of Southern Rhodesia, December 16, 1966, as attachment to letter to President Johnson from Walt W. Rostow, December 31, 1968, "Rhodesia, vol. 2 (1 of 3)," Country File, NSF, box 97, LBJL; United Nations Security Council Resolution 253, as attachment to letter to President Johnson from Walt Rostow, December 31, 1968, "Rhodesia, vol. 2 (1 of 3)," Country File, NSF, box 97, LBJL. 
opposition to white supremacy and the wish to retain prestige in black Africa, however, dictated that Washington adopted a posture of hostility toward Salisbury. ${ }^{15}$

During the tortuous negotiations between London and Salisbury in the years preceding UDI, the White House closely monitored the course of negotiations and repeatedly emphasized to the Rhodesians the gravity of the situation and the extent of U.S. support for Britain. Indeed, Johnson himself sent a personal message to Smith expressing his hope that Salisbury would "avoid a course which, in addition to all its other consequences, would inevitably break the strong ties of friendship and understanding which have bound our countries together in war and peace."16

\footnotetext{
${ }^{15}$ Memorandum to Ambassadors and Certain Principal Officers from Assistant Secretary of State G. Mennen Williams, May 10, 1965, “Africa General, vol. 2 (3 of 4),” Country File, NSF, box 76, LBJL; Memorandum for the President from Robert Komer, November 23, 1965, “Africa General, vol. 3,” Country File, NSF, box 76, LBJL; Memorandum for President Johnson from Robert Komer, December 6, 1965, Files of Edward K. Hamilton, NSF, box 3, LBJL; Memorandum for Walt Rostow from Rick Haynes, Balance Sheet: Rhodesian Crisis, April 22, 1966, "Rhodesia, vol. 2 (3 of 3)," Country File, NSF, box 97, LBJL; National Intelligence
} Estimate Number 60/70-65: Problems and Prospects in Sub-Saharan Africa, April 22, 1965, “60/70, Africa," National Intelligence Estimates File, NSF, box 8, LBJL; Summary Notes of 567th NSC Meeting, January 25, 1967, “vol.4 Tab 49 Southern Rhodesia,” NSC Meetings File, NSF, box 2, LBJL; Backgrounder: The President's Concern for Africa, “Chrono (1 of 3)," Files of Ulric Haynes, NSF, box 1, LBJL; Memorandum of Telephone Conversation between the Special Assistant for National Security Affairs Bundy and Acting Secretary of State Ball, October 5, 1965, FRUS, vol. XXIV, doc. 475.

${ }^{16}$ Message from Dean Rusk to Harold Wilson via the U.S. Embassy, October 23, 1965, PREM 13/542, TNA; Memorandum for President Johnson from Robert Komer, October 25, 1965, "Chrono (2 of 3)," Files of Ulric Haynes, NSF, box 1, LBJL; White House Situation Report for McGeorge Bundy from Rick Haynes, Rhodesian UDI, October 30, 1965, "Rhodesia, vol. 1 (3 of 3)," Country File, NSF, box 97, LBJL; Telegram from Secretary of State to American Consulate General Salisbury, October 29, 1965, "Rhodesia, vol. 1 (1 of 3)," Country File, NSF, box 97, LBJL. 
Following UDI, the U.S. imposed its own sanctions program that mirrored British measures, which included an oil embargo on Rhodesia and an airlift to help neighboring Zambia with its resultant oil shortages. At the UN, Washington supported British actions including the imposition of both selective and comprehensive mandatory sanctions and issued subsequent executive orders, which, under Section 5 of the United Nations Participation Act, enacted into domestic law the provisions of the UN resolutions. ${ }^{17}$

The White House, though was not prepared to support more radical actions against Salisbury, including the use of force or broader sanctions against South Africa, which served as a conduit for Rhodesian trade, because such measures would threaten Western interests, lead to a potential military confrontation with Pretoria, and could intensify political and social ethnic tensions in the U.S. itself. ${ }^{18}$

\footnotetext{
${ }^{17}$ Notes of Telephone Conversation, November 12, 1965, FRUS, vol. XXIV, doc. 493; Memorandum for McGeorge Bundy from Gordon Chase, Southern Rhodesia-Security Council Statement, November 12, 1965, “Rhodesia, vol. 1 (3 of 3)," Country File, NSF, box 97, LBJL; Chapter 10 (The United Nations) Sections C, D, and E, Department of State Administrative History vol. 1, box 4, LBJL; Resolution Adopted by the Security Council, Question of Southern Rhodesia, as Attachment to Letter to President Johnson from Walt Rostow, December 31, 1968, "Rhodesia, vol. 2 (1 of 3)," Country File, NSF, box 97, LBJL; White House Executive Order 11322, Relating to Trade and Other Transactions Involving Southern Rhodesia, Office of White House Press Secretary, January 5, 1967, CO 250 Federation of Rhodesia-Nyasaland, White House Central Files (hereafter WHCF), box 11 (1 of 2), LBJL; United Nations Security Council Resolution 253, as Attachment to Letter to President Johnson from Walt Rostow, December 31, 1968, "Rhodesia, vol. 2 (1 of 3)," Country File, NSF, box 97, LBJL; Executive Order 11419: Relating to Trade and Other Transactions Involving Southern Rhodesia, as Attachment to Letter to President Johnson from Walt W. Rostow, December 31, 1968, "Rhodesia, vol. 2 (1 of 3)," Country File, NSF, box 97, LBJL.

${ }^{18}$ Memorandum to McGeorge Bundy from Robert Komer, January 6, 1965, “Africa General, vol. 2 (2 of 4),” Country File, NSF, box 76, LBJL; Memorandum for the Secretary of State from McGeorge Bundy, January 7 , 1965, “Africa General, vol. 2 (2 of 4),” Country File, NSF, box 76, LBJL; Memorandum to Robert Komer from Rick Haynes, March 25, 1965, “Africa General, vol. 2 (2 of 4),” Country File, NSF, box 76, LBJL; Department
} 
The Johnson administration's approach to Rhodesia was cautious and measured. His successor in the Oval Office, however, would shift U.S. policy toward a closer association with the white minority regimes and openly violate of UN sanctions.

\section{Nixon}

On January 20, 1969, Richard Milhous Nixon was inaugurated as President of the United States. In the presidential campaign of 1968, Nixon had been elected to a large extent due to the conservative resurgence of a middle class angered and tired by the liberalism and radical politics of the 1960s and the new president swiftly surrounded himself with advisers who stood for traditional conservative values including anti-communism.

On a conceptual level, the foreign policy of the Nixon years, as shaped by Secretary of State Henry A. Kissinger, was characterized by a preoccupation with the balance of power linked to a form of global federalism with the United States at the apex of a multipolar pyramid of nations. Kissinger believed that in such a system both of the two superpowers would feel less directly threatened by each other's every action and also U.S. leverage would increase as regional allies voluntarily shouldered the responsibility to protect their areas of the globe from communist encroachment. ${ }^{19}$

Southern Africa, while not a major priority for the new administration when compared to the broader goals of détente such as improving relations with China and ending

of State Research Memorandum to Acting Secretary of State Ball from Director of Intelligence and Research Thomas L. Hughes, UDI Developments and Reactions, November 16, 1965, "Rhodesia, vol. 1 (3 of 3)," Country File, NSF, box 97, LBJL; Memorandum for President Johnson from Robert Komer, December 6, 1965 , Files of Edward K. Hamilton, NSF, box 3, LBJL; Summary Notes of the 567th Meeting of the NSC, January 25, 1967, FRUS, vol. XXIV, doc. 556; Horne, From the Barrel of a Gun, 15.

${ }^{19}$ Jeremi Suri, "Henry Kissinger and the Geopolitics of Globalization," in The Shock of the Global, ed. Ferguson et al.173-84. 
the war in southeast Asia, was nonetheless important. Chaos on the "periphery" would complicate the broader geopolitical mission either by affecting domestic opinion or inviting communist expansion. Kissinger, in particular, was concerned by the appeal of Marxist ideology for anti-colonial leaders. The Nixon Doctrine of 1969 advocated the pursuance of strategic interests not by direct military intervention but through military and other aid to friendly governments. These governments could include unpalatable regimes provided they had distinctively anti-communist credentials. In sub-Saharan Africa, in practical terms this meant closer ties with the white regimes. ${ }^{20}$

A second strategic issue affecting relations with southern Africa was access to chrome. Chromium, which is commercially produced from chromite ore, was a metal of high economic value due to its corrosion resistance and strength. In the late 1960s, chrome and chrome-based products including ferroalloys and stainless steel were vital components of a number of U.S. industries including electric power generation and chemical manufacturing. The National Aeronautics and Space Administration (NASA) space program also used chrome. Chrome's strategic importance was reflected by its inclusion on the Strategic and Critical List from the Office of Emergency Preparedness (OEP). ${ }^{21}$

Chromite ore, however, is not widely distributed in the earth's crust. Washington's problem was that the United States contains no deposits of chromite ore, leaving the U.S. dependent on global imports. Prior to UDI, Rhodesia had been a major supplier of chromite ore to the United States. Indeed, according to industry insiders, Rhodesia was the source of

\footnotetext{
${ }^{20}$ Lawrence, “Containing Globalism,” 209-10 and Henry Kissinger, White House Years (London, 1979), 69.

${ }^{21}$ Statement of J. Clayton Stephenson, President, Mining and Metals Division, Union Carbide Corporation, October 31, 1969 before Subcommittee on Africa of the House Committee of Foreign Affairs, NSC Country Files, Rhodesia (1969-1970), box 743, RNPL; Statement of L. G. Bliss, Chairman of the Board and President of Foote Mineral Company, before the Subcommittee on Africa of the House Committee on Foreign Affairs October 31, 1969, NSC Country Files, Rhodesia (1969-1970), box 743, RNPL.
} 
the finest chromite ore on the planet. U.S. mining interests were also some of the principal investors in the Rhodesian chrome industry. Adherence to the UN sanctions on Rhodesia, though, had led the United States to develop a growing dependence on ore from the USSR. This was not only deemed unwise strategically but was hurting U.S. businesses due to inflated prices and inferior quality. By 1969, the scarcity of chrome was beginning to concern several government departments including Commerce and the OEP. ${ }^{22}$

Nixon and Kissinger were also not immune to cultural prejudices when formulating policy on Africa. Indeed, as DeRoche points out, Nixon repeatedly snubbed Zambian President Kenneth Kaunda during his visits to Washington as well as emissaries from the Organization of African Unity. In Kissinger's view, the former colonial nations of Africa deserved little respect because of their lack of political tradition, immature economies and weak militaries. On one notable occasion in September 1971, when Kissinger referred to the African delegation accompanying Mauritanian President Moktar Ould Daddah in Washington as "savages," Nixon responded with laughter. ${ }^{23}$

\footnotetext{
${ }^{22}$ Statement of J. Clayton Stephenson, President, Mining and Metals Division, Union Carbide Corporation, October 31, 1969 before Subcommittee on Africa of the House Committee of Foreign Affairs, NSC Country Files, Rhodesia (1969-1970), box 743, RNPL; Letter to Tom Charles Huston, Staff Assistant to the President from L. G. Bliss, President of Foote Mineral Company, June 5, 1969, NSC Country Files, Rhodesia (19691970), box 743, RNPL; Memorandum for President Nixon from Maurice H. Stans, Rhodesian Sanctions:
} Response to National Security Decision Memorandum (hereafter NSDM) 47, May 15, 1970, NSC Institutional (“H”) Files, NSDM 47, box H-214, RNPL.

${ }^{23}$ Andy DeRoche, "KK, the Godfather, and the Duke: Maintaining Positive Relations between Zambia and the USA in Spite of Nixon's Other Priorities," Safundi 12, no. 1 (2011): 97, doi:10/80/175.2011.533915; Kissinger, White House Years, 69; Richard Nixon, The Memoirs of Richard Nixon (New York, 1978), 283; Suri, "Henry Kissinger and the Geopolitics of Globalization," 186; Conversation between President Nixon and the President's Assistant for National Security Affairs Kissinger, September 28, 1971, FRUS, 1969-1976, vol. XXVIII, Southern Africa (Washington, DC, 2011), doc. 57. 
Domestically, as noted by Horne, a key element in Nixon's electoral success was the "Southern Strategy." Nixon won over white voters in the southern states, traditionally a stronghold for the Democratic Party, by assuring conservatives he would slow federal enforcement of civil rights laws. Indeed, Nixon himself was reluctant on ideological grounds to force change on de facto segregated communities as he believed that busing and other strategies to promote integration would foment unnecessary social tensions. ${ }^{24}$

Parallels existed between the White House's domestic approach to civil rights and its relations with the white governments of southern Africa. In both cases, Nixon publicly condemned racism and racially discriminatory laws, yet was reluctant to push for meaningful change. Indeed, many of Rhodesia's most vocal supporters not only hailed from former Confederate states and held racist views but many also enjoyed close ties to Nixon himself. ${ }^{25}$ The most notable example of this was Senator James Eastland (D-Mississippi), a man renowned for his opposition to civil rights and considered by Nixon to be a vital ally. Ken Flower, the Head of the Rhodesian Central Intelligence Organization, noted Senator Eastland's unsavory racial views. On a visit to Salisbury, Eastland, upon witnessing black and white Rhodesians mingling in a Salisbury hotel, rebuked his hosts stating "You've inserted the thin end of the wedge by allowing stinking niggers into such a fine hotel." ${ }^{26}$

The Nixon Administration was also confronted by an increasingly confident and assertive Rhodesian government. As noted by Central Intelligence Agency (CIA) Director Richard Helms, Salisbury, buoyed by Portuguese and South African support, had successfully

\footnotetext{
${ }^{24}$ Horne, From the Barrel of a Gun, 7; Nixon, The Memoirs of Richard Nixon, 439-40.

${ }^{25}$ Joseph Crespino, Strom Thurmond's America (New York, 2013), 71, 193; Nixon, The Memoirs of Richard Nixon, 669.

${ }^{26}$ Ken Flower, Serving Secretly: An Intelligence Chief on Record, Rhodesia into Zimbabwe 1964 to 1981 (London, 1987), 150.
} 
circumvented international sanctions, the economy was relatively prosperous, the country was well endowed with natural resources, and the trade embargo and pariah status of Rhodesia had created a "state of siege" mentality that had bolstered support for Smith and the Rhodesian Front. $^{27}$

The Rhodesian military was more than capable, especially with South African support, of defeating any threat from black African countries. Furthermore, the so-called Front Line states would also suffer economically if trade with the white controlled nations was cut off. Domestically, the black Rhodesian population was "quiescent" and the externally based insurgent movements had been ineffective due in part to the power of the security forces. $^{28}$

Although the claim by Rhodesian Commentary, published by the Rhodesian Information Office (RIO) in Washington D.C., that millions of U.S. citizens opposed sanctions on Rhodesia must be treated with skepticism, presidential correspondence reflected a pro-Rhodesia bias among many in the American public. Rhodesia, certainly possessed strong political supporters including former Secretary of State and informal White House adviser Dean Acheson. ${ }^{29}$

\footnotetext{
${ }^{27}$ NSC Interdisciplinary Group for Africa, Study in Response to NSSM 39: Southern Africa, August 15, 1969, NSC Institutional ("H”) Files, NSSM-39 2 of 3 (1 of 2), box H-144, RNPL; Briefing by Richard Helms, Director of Central Intelligence for the NSC, December 17, 1965, NSC Institutional ("H") Files, NSSM-39 3 of 3 (2 of 4), box H-145, RNPL.

${ }^{28}$ NSC Interdisciplinary Group for Africa, Study in Response to NSSM 39: Southern Africa, August 15, 1969, NSC Institutional (“H”) Files, NSSM-39 2 of 3 (1 of 2), box H-144, RNPL; Briefing by Richard Helms, Director of Central Intelligence for the NSC, December 17, 1965, NSC Institutional ("H") Files, NSSM-39 3 of 3 (2 of 4), box H-145, RNPL.

${ }^{29}$ Flower, Serving Secretly, 150; Horne, From the Barrel of a Gun, 7; Nixon, The Memoirs of Richard Nixon, 669; Rhodesian Commentary October 14, 1968, CO 124 Rhodesia Begin-12/31/69, WHCF, box 63, RNPL.
} 
On the question of Rhodesia, the Department of State and the U.S. Mission to the United Nations favored a continuation of existing policy or further dissociation from Salisbury and closer identification with black Africa. Other government departments, however, including Commerce, Defense, Treasury, and the OEP urged Nixon to consider a relaxation of posture toward the Smith government on strategic and economic grounds. Kissinger and the National Security Council (NSC) also supported this view. ${ }^{30}$

The new administration came into office determined to reshape foreign policy. Specifically, the president and his advisers wished to move away from the liberal agenda of the Sixties, notably crisis management and pouring energy and resources into poverty stricken states in Africa, Asia, and Latin America in the hopes of achieving political and social improvements. In their view, these policies had failed to deal with the deeper underlying causes of the global crises or stimulate greater democracy as demonstrated by the rise of totalitarian, often Marxist, regimes. In Kissinger's words, when Nixon took office, it was imperative to "articulate a new foreign policy for a new era." 31

In order to impose a new blueprint on policy, Kissinger, in the spring of 1969, began to inundate the State Department with requests for comprehensive policy reviews of U.S. relations and interests worldwide. On April 3, at the recommendation of the NSC staff member for African Affairs, Roger P. Morris, Kissinger urged Nixon to order a National Security Study Memorandum (NSSM) on southern Africa. Kissinger argued that there had been no comprehensive high level of U.S. interests and objectives in southern Africa since the Kennedy era of the early 1960s. Since that time, however, the situation had become

\footnotetext{
${ }^{30}$ Issues for Decision, NSC Meeting 12/17/69, NSC Institutional (“H”) Files, Southern Africa (NSSM 39) (3 of 3), box H-026, RNPL; Lake, The "Tar Baby” Option, 125-26.

${ }^{31}$ Lawrence, "Containing Globalism,” 205; Kissinger, White House Years, 65.
} 
increasingly volatile due to the appearance of the USSR and China as patrons of the black guerrilla groups. $^{32}$

Furthermore, as Kissinger noted, the United States had meaningful yet potentially conflicting interests in the area that needed to be clearly identified and weighed. While there were political advantages in repudiating the repressive policies of the so-called White Redoubt, there were also material interests that required involvement with those same governments. It was necessary for the NSC to be able to consider all the possible options in dealing with the white minority-controlled nations. ${ }^{33}$

On August 15, 1969, the Interdepartmental Group completed its response to NSSM 39. As an overview, the group noted the important U.S. strategic and economic interests in the white-controlled states, notably South Africa, including the approximately $\$ 1$ billion in investments, a highly favorable balance of payments, an important NASA tracking station, and key geographic position. In the case of Rhodesia, the group observed that before UDI Salisbury provided between a quarter and a third of chromite imports before sanctions and pointed out that the Rhodesian Government currently controlled a number of U.S. owned

\footnotetext{
32 Memorandum for the President from Henry Kissinger, NSC Review of Policy toward Southern Africa, April 3, 1969, NSC Institutional ("H”) Files, NSSM-39 3 of 3 (1 of 4), box H-144, RNPL; Memorandum from Assistant for National Security Affairs Kissinger to President Nixon, NSC Review of Policy toward Southern Africa, April 3, 1969, FRUS, vol. XXVIII, doc. 5; Memorandum for the President from Henry Kissinger, NSC Review of Policy toward Southern Africa, April 3, 1969, NSC Institutional ("H”) Files, NSSM-39 3 of 3 (1 of 4), box H-144, RNPL; Lake, The “Tar Baby” Option, 124.

${ }^{33}$ Memorandum for the President from Henry Kissinger, NSC Review of Policy toward Southern Africa, April 3, 1969, NSC Institutional (“H”) Files, NSSM-39 3 of 3 (1 of 4), box H-144, RNPL.
} 
mining enterprises. The group also noted that U.S. investment in Rhodesia amounted to around $\$ 56$ million. ${ }^{34}$

The study pointed out, however, that U.S. interests in the white-dominated states were seen as at least tacit acceptance of racism, which affected U.S. standing with other African states and was also considered a reflection on Washington's stance on domestic racism. The group also noted that U.S. investments in black Africa were valued at around $\$ 1.5$ billion and trade relations were expanding. Increasing violence in the region stemming from black insurgency and white reprisal posed a real threat to U.S. interests. The group observed, though, that "There is no likelihood in the foreseeable future that liberation movements could overthrow or seriously threaten the existing white governments." 35

The Interdepartmental Group response to NSSM 39 laid out a number of options for the NSC to consider including closer relations with the white regimes, a broader association with both black and white states, dissociation from white Africa, and more broadly detachment from the whole southern African region to avoid any form of formal U.S. involvement in the racial problems of the area. ${ }^{36}$

On October 16, 1969, the NSC Review Group met to discuss the findings of the interdepartmental paper. On the day before the meeting, NSC staffers Charles H. Hermann, Richard T. Kennedy, and Morris had suggested several talking points to Kissinger. Notably they focused on the fact that the white governments were in firm control and that violence, which the black states were ill equipped to engage in, would not bring change. International attempts to isolate the whites had failed and led to the creation of a siege mentality, not

\footnotetext{
${ }^{34}$ NSC Interdisciplinary Group for Africa, Study in Response to NSSM 39: Southern Africa, August 15, 1969, NSC Institutional (“H”) Files, NSSM-39 2 of 3 (1 of 2), box H-144, RNPL.

35 Ibid.

${ }^{36}$ NSC Interdisciplinary Group for Africa, Study in Response to NSSM 39: Southern Africa, August 15, 1969, NSC Institutional (“H”) Files, NSSM-39 2 of 3 (1 of 2), box H-144, RNPL; Lake, The “Tar Baby” Option, 128.
} 
moderation. It was also noted that the black African reaction to increased relations with the white states would be limited to rhetoric alone as their nations needed U.S. support and aid money. ${ }^{37}$

At the meeting it was agreed to reformulate the options proposed by the Interdepartmental Group prior to the upcoming NSC meeting in December. The revised options fell into three broad categories: relaxation of relations with the white regimes, limited association, and disengagement. Within each broad posture there were two operationally different options, which created a total of six possibilities for consideration.

The first, known at the time as the "Acheson Option," was a normalization of U.S. relations with white-ruled Africa. This would include the termination of arms embargoes on South Africa and the Portuguese territories as well as the gradual cessation of sanctions enforcement on Rhodesia. A similar but less politically explosive option was the selective broadening of ties with both white and black states to encourage moderation and protect interests on both sides. This would mean a relaxation but not withdrawal from Rhodesian sanctions and the South African arms embargo combined with an increase in aid to black states. ${ }^{38}$ The third and fourth possibilities involved increased identification with the black states to permit the U.S. to pursue minimally necessary interests in the white states. A fifth option was greater dissociation from the white regimes to enhance standing on the racial issue in Africa and globally. The final choice for the White House was to engage in the broadest

\footnotetext{
${ }^{37}$ Memorandum for Henry Kissinger from Richard T. Kennedy, Charles H. Hermann and Roger Morris, Southern Africa-NSC Review Group, October 15, 1969, NSC Institutional (“H”) Files, Southern Africa 10/16/69, box H-040, RNPL.

${ }^{38}$ NSC Review Group Meeting, Southern Africa (NSSM 39), October 16, 1969, NSC Institutional (“H”) Files, NSSM-39 3 of 3 (4 of 4), box H-145, RNPL; Issues for Decision, NSC Meeting December 17, 1969, NSC Institutional (“H”) Files, Southern Africa (NSSM 39) (3 of 3), box H-026, RNPL.
} 
possible coercive measures, short of armed force, to induce change in the racial policies of white states. ${ }^{39}$

The second option, the selective broadening of ties with the white governments, appealed to a number of agencies. The Department of Commerce supported it because it would expand U.S. exports. Treasury liked the potential balance of payments; OEP wanted access to Rhodesian chrome while Defense believed it would protect important strategic, scientific, and economic interests. Kissinger and the NSC staff also favored a relaxation of posture along the lines set out by the Interdepartmental Group. ${ }^{40}$

It is important to note that while NSSM 39 primarily focused on South Africa, the economic giant and preeminent military power in the region, Rhodesia, was not included, as some commentators suggested, as a mere afterthought. In fact, in the case of Rhodesia, it would be far more difficult for the United States to adopt a policy of "communication" given the international illegality of the regime and the claim of de jure British sovereignty. ${ }^{41}$

The NSC meeting was held on December 17, 1969. The minutes clearly indicate that participants' primary concerns lay with the geostrategic and economic interests of their particular departments. Commerce highlighted the large amount of trade and investment the United States had in southern Africa and urged, along with OEP Director General George A.

\footnotetext{
${ }^{39}$ NSC Review Group Meeting, Southern Africa (NSSM 39), October 16, 1969, NSC Institutional (“H”) Files, NSSM-39 3 of 3 (4 of 4), box H-145, RNPL; Issues for Decision, NSC Meeting December 17, 1969, NSC Institutional (“H”) Files, Southern Africa (NSSM 39) (3 of 3), box H-026, RNPL.

${ }^{40}$ Issues for Decision, NSC Meeting December 17, 1969, NSC Institutional (“H”) Files, Southern Africa (NSSM 39) (3 of 3), box H-026, RNPL; Memorandum for the President from Secretary of Commerce Maurice Stans, U.S. Policy Toward Southern Africa, December 12, 1969, NSC Meeting 12/17/69, NSC Institutional (“H”) Files, Southern Africa (NSSM 39) (3 of 3), box H-026, RNPL.

${ }^{41}$ Issues for Decision, NSC Meeting, December 17, 1969, NSC Institutional ("H”) Files, Southern Africa (NSSM 39) (3 of 3), box H-026, RNPL; Lake, The “Tar Baby” Option, 123.
} 
Lincoln, the president to consider the importation of chrome. On the issue of the continued presence of a consulate in Salisbury, CIA Director Helms opposed closure on the grounds that the United States would lose an important source of intelligence. ${ }^{42}$

Nixon himself favored some form of "relaxation" of relations with the white regimes. He stated that the United States "must analyze where our national interest lies and not worry too much about other peoples' domestic policies.” He further discounted black political aspirations and abilities by observing that the whites in South Africa, while only 6 percent of the population, produced 40 percent of the continent's GNP and that they were they were there to stay. ${ }^{43}$

On January 28, 1970, Nixon issued National Security Decision Memorandum (NSDM) 38. On Kissinger's advice, the president had selected a policy along the lines of partial relaxation. This represented a significant change in policy toward southern Africa. Instead of being guided by the principle of political disassociation with the white regimes, the White House now sought greater "communication" with Pretoria, the Portuguese territories, and to a lesser extent Salisbury. ${ }^{44}$

The habitually secretive Nixon chose to keep this new policy approach not only away from the news media and the public but also from most government personnel. White House officials apparently preferred that the shift toward the white regimes not be revealed because

\footnotetext{
${ }^{42}$ Minutes of the NSC Meeting on Southern Africa, December 17, 1969, NSC Institutional (“H”) Files, NSSM393 of 3 (2 of 4), box H-145, RNPL.

43 Ibid.

${ }^{44}$ Memorandum for the President from Henry Kissinger, Decisions on Southern African Policy, January 15, 1970, NSC Institutional (“H”) Files, NSSM-39 3 of 3 (4 of 4), box H-145, RNPL; Memorandum from Henry Kissinger to the Vice President, Secretary of State, Secretary of the Treasury, Secretary of Defense, Attorney General, Secretary of Commerce, Director of Emergency Preparedness, NSDM 38, United States Policy toward Southern Africa, January 28, 1970, NSC Institutional (“H”) Files, NSSM-39 3 of 3 (2 of 4), box H-145, RNPL.
} 
it was to be a quiet and protracted relaxation of U.S. relations that would only become evident over time. It is also clear that the White House was aware of the potential political firestorm that such a shift in policy would cause among liberals and African-Americans. The niceties of a foreign policy that proclaimed an abhorrence of white minority rule but conducted business as usual with its practitioners would be lost on those who identified with oppressed blacks in southern Africa. ${ }^{45}$

By this point, the issue of chrome had developed into a focal political question in Washington. Under Executive Order 11322, signed by President Johnson, the U.S. was legally bound by mandatory UN sanctions that prohibited the importation of Rhodesian chrome. Nixon, however, had already been urged by a number a high profile political figures including Senator Strom Thurmond (R-South Carolina), Senator Eastland, and Acheson to repeal sanctions and allow the flow of Rhodesian chrome back into the United States. The Department of Commerce and the OEP had also pressed for the re-importation of Rhodesian chrome. $^{46}$

\footnotetext{
45 Memorandum for the President from Henry Kissinger, Decisions on Southern African Policy, January 15, 1970; Memorandum from Henry Kissinger to the Vice President, Secretary of State, et al., NSDM 38, United States Policy toward Southern Africa, January 28, 1970; Memorandum for Henry Kissinger from Richard Kennedy and Roger Morris, NSC Meeting on South Africa, December 17, 1969, NSC Meeting 12/17/69, NSC Institutional (“H”) Files, Southern Africa (NSSM 39) (3 of 3), box H-026, RNPL.

${ }^{46}$ Congressional Record, Proceedings and Debates of the 90th Congress, Second Session vol. 114, October 12, 1968, WHCF, CO 124 Rhodesia Begin-12/31/69, box 63, RNPL; Paper to Henry A. Kissinger from Dean Acheson, U.S. Policies Toward Southern Africa Require Change, April 30, 1969, WHCF, CO 135 South Africa, Republic of (1969-70), box 63, RNPL; Letter to President Nixon from Congressman Howard W. Pollock, July 23, 1969, NSC Country Files, Rhodesia (1969-1970), box 743, RNPL; Letter to Clark Mollenoff from Senator James O. Eastland (D-Mississippi), March 19, 1970, WHCF, CO 124 Rhodesia 5/1/70-8/31/70, box 63, RNPL; Letter to the President from Senator Strom Thurmond, April 15, 1970, NSC Country Files, Rhodesia vol. 2
} (1970-1974), box 743, RNPL. 
On April 16, 1969, Union Carbide Corporation submitted an application to import 150,000 tons of chrome ore under the "hardship exemption" that had accompanied the Executive Order of January 1967. Two other companies, Foote Mineral and Corning Glass, had also applied for exemptions to import chrome and petalite respectively. The "exemption" to Executive Order 11322 allowed Rhodesian goods that had been paid for but not exported before January 5, 1967 to be licensed for import on the grounds of undue hardship. The application of Corning Glass did not fall under this criteria and was easily dismissed. The other two cases would prove far harder to decide. ${ }^{47}$

Union Carbide had been active in Rhodesia since 1923. By 1969 the company had a gross investment of \$17 million in the UDI state. It operated through two affiliated companies: Rhodesia Chrome Mines Limited and Africa Chrome Mines Limited. On November 14, 1966, Union Carbide paid \$2 million to Ruighoek Chrome Mines, a subsidiary in South Africa that was responsible for the distribution of Rhodesia Chrome Mines. On December 16, a further \$1 million was paid to Ruighoek, which then five days later transferred $\$ 2,680,000$ to Rhodesia Chrome Mines as payment for 150,000 tons of chrome ore for export to the United States. ${ }^{48}$

The case of Foote Mineral was somewhat different. The company had been present in Rhodesia since 1932 as the sole owner of Rhodesian Vanadium Corporation. In January 1967 the company orally requested the permission of the Treasury Department to transfer $\$ 74,000$ a month to its subsidiary in order to allow minimum production, which would prevent the

\footnotetext{
${ }^{47}$ Memorandum for Henry Kissinger from Acting Secretary of Commerce K. N. Davis Jr., December 24, 1969, NSC Country Files, Rhodesia (1969-1970), box 743, RNPL; Lake, The “Tar Baby” Option, 148.

${ }^{48}$ Memorandum for Henry Kissinger from Acting Secretary of Commerce K. N. Davis Jr., December 24, 1969; Statement of J. Clayton Stephenson, President, Mining and Metals Division, Union Carbide Corporation, before Subcommittee on Africa of the House Committee of Foreign Affairs, October 31, 1969, NSC Country Files,
} Rhodesia (1969-1970), box 743, RNPL. 
mine from flooding. The transfer of the funds was solely for the maintenance of the mine and the ore produced was kept stockpiled above ground. On January 2, 1968, the Rhodesian government took over the operation. Claiming that there would no further financial benefit to the Smith regime as the chrome had already been paid for, Foote Mineral submitted two applications, on September 27, 1967 and August 28, 1968, to the Treasury Department to import 57,000 tons of chrome ore mined after January 1967. Treasury refused both. ${ }^{49}$

In the spring of 1969, on the advice of White House staffer, Patrick Buchanan, Nixon overruled State Department objections to the importation of the ore by Union Carbide and Foote Mineral and asked Kissinger to implement the decision. Kissinger, however, advised Nixon that it would be more prudent to wait and only consider specific actions after the NSC review on southern Africa. Kissinger was concerned that not only were the legal aspects of the case in dispute among government departments but that neither the black African nations nor the Rhodesian government would see it as a simple deal. There were also fears that acceptance would leave the administration open to domestic criticism from the left. ${ }^{50}$

In NSDM 38, Nixon ordered that representatives from State, Treasury, and Commerce study the Union Carbide case under the chairmanship of the Justice Department to clarify its status under present regulations. On January 28, Deputy Attorney General Richard

\footnotetext{
${ }^{49}$ Memorandum for Henry Kissinger from Acting Secretary of Commerce K. N. Davis Jr., December 24, 1969; Statement of L. G. Bliss, Chairman of the Board and President of Foote Mineral Company, before the Subcommittee on Africa of the House Committee on Foreign Affairs, October 31, 1969, NSC Country Files, Rhodesia (1969-1970), box 743, RNPL.

${ }^{50}$ Memorandum for Henry Kissinger from Bob Haldeman, May 1, 1969, NSC Institutional (“H”) Files, NSSM391 of 3 (1 of 3), box H-144, RNPL; Memorandum for Bob Haldeman from Henry Kissinger, Rhodesian Chrome Imports, May 7, 1969, NSC Institutional (“H”) Files NSSM - 391 of 3 (1 of 3), box H-144, RNPL.
} 
Kleindienst submitted to the White House the opinion that Union Carbide should receive approval. $^{51}$

The State Department, however, opposed an exemption on the grounds that the company had paid the monies after the UNSC had passed mandatory sanctions and that granting an exemption would also lead to accusations that the United States had brought about the collapse of sanctions. At the other extreme, Commerce and the OEP were opposed to the overall embargo on chrome imports as it left the United States excessively dependent on the USSR for chrome and vulnerable to Soviet manipulation of prices. ${ }^{52}$

The administration also began to feel increased pressure from political allies who urged Nixon to approve both applications. On March 19, Senator Eastland, in a letter to the White House, expressed concern about the U.S. refusal to protect its own strategic interests. He argued that the strict compliance with sanctions was cutting Washington off from an

\footnotetext{
${ }^{51}$ Memorandum from Henry Kissinger to the Vice President, Secretary of State, et al., NSDM 38, United States Policy toward Southern Africa, January 28, 1970; Memorandum to Richard G. Kleindienst, Deputy Attorney General, Department of Justice from John R. Stevenson, Legal Advisor, Department of State, Union Carbide Application to Import Rhodesian Chrome, February 5, 1970, NSC Institutional ("H”) Files, NSDM 38, NDSM Working Files, box H-213, RNPL; Memorandum to Henry Kissinger Assistant from Deputy Attorney General Richard G. Kleindienst, RE: Paragraph No. 2 of NSDM 38, NSC Institutional (“H”) Files, February 9, 1970, NSDM 38, NDSM Working Files, box H-213, RNPL; Lake, The “Tar Baby” Option, 151-52.

${ }^{52}$ Memorandum for the President from the Secretary of State, Rhodesian Sanctions: Response to NSDM 47, April 29, 1970, NSC Institutional (“H”) Files, NSDM-47, box H-214, RNPL; Memorandum for Henry Kissinger from G. A. Lincoln, Comment on the NSDM 47 Study, May 1, 1970, NSC Institutional (“H”) Files, NSDM-47, box H-214, RNPL; Memorandum for the President from Secretary of Commerce Maurice Stans, Rhodesian Sanctions: Response to NSDM-47, May 15, 1970, NSC Institutional (“H”) Files, NSDM-47, box H214, RNPL; Memorandum for the President from Henry Kissinger, Rhodesian Sanctions, July 23, 1970, NSC Institutional (“H”) Files, NSDM-47, box H-214, RNPL.
} 
abundant and dependable source of high-grade chrome ore in Rhodesia leaving the United States now heavily dependent on Moscow. ${ }^{53}$

One month later, Senator Thurmond also wrote to the President and informed him that he would gain greater support from Republican voters by rescinding the executive order that banned chrome imports. According to Thurmond, the embargo threatened national security due to dependence on the USSR for chrome and was imposed without sufficient basis in law because the UN Charter forbade interference in internal affairs of states. Furthermore, the embargo had only served to alienate Salisbury, leading to the adoption of more extreme policies. $^{54}$

On August 7, the NSC reviewed the issue of chrome imports and specifically the two cases for hardship exemptions. Two days later, Nixon issued NSDM 75, which approved the Union Carbide application, contingent upon the confirmation by Treasury of the facts stated by the company on their application, and further approved licenses for U.S. firms to sell their assets in Rhodesia to any buyer. The application by Foote Mineral was rejected but the company remained defiant, stating in The Star, a South African newspaper, that the company had no plans to sell its chrome assets in Rhodesia. It would not be long, however, before the Byrd Amendment allowed Foote Mineral, Union Carbide, and any other U.S. company to import as much Rhodesian chrome as they desired. ${ }^{55}$

\footnotetext{
${ }^{53}$ Letter to Clark Mollenoff from Senator James O. Eastland (D-Mississippi), March 19, 1970, WHCF, CO 124 Rhodesia 5/1/70-8/31/70, box 63, RNPL.

${ }^{54}$ Letter to the President from Senator Strom Thurmond, April 15, 1970, NSC Country Files, Rhodesia vol. 2 (1970-1974), box 743, RNPL.

55 Memorandum for the President from Henry Kissinger, Rhodesian Sanctions, July 23, 1970, NSC Institutional (“H”) Files, NSDM-47, box H-214, RNPL; To The Vice President et al. from Henry Kissinger, NDSM 75, August 7, 1970, FRUS, vol. XXVIII, doc. 39. Letter to Henry Kissinger, from Anthony J. Jurich, Special Assistant to the Secretary for National Security Affairs, Office of the Secretary of the Treasury, August 24,
} 
As early as the fall of 1968 , the question of allowing the full importation of Rhodesian chrome had been raised in Congress. This issue took on a new urgency in 1970 when Senator Eastland used this argument to advocate for Senate Resolution 367, which would have restored trading relations with Rhodesia. While the Eastland bill failed to pass, by early 1971 pro-Rhodesia supporters in Congress had devised a new formula to obtain Rhodesian chrome. $^{56}$

On February 22, 1971 Representative James Collins (R-Texas) introduced House Resolution 4712, which sought to amend the UN Participation Act of 1945 to repeal prohibitions on the importation of any metal-bearing ore from a free world country as long as the importation of the same ore from a communist country was not prohibited by law. In other words, Collins sought to legitimize chrome imports from "free world" Rhodesia by a legal justification that the United States had been importing chrome from the "communist" Soviet Union. On March 3, the term "metal bearing ore" was deleted and replaced by “strategic and critical material.” Within weeks Senator Harry F. Byrd Jr. (I-Virginia) proposed a similar bill as Senate Resolution $1404 .^{57}$

In June, the House Foreign Affairs Committee met to consider H.R. 4712. Collins made an impassioned argument, which not only noted the danger of the Russian monopoly on chrome but also observed that on the issue of race the proportion of blacks in the Rhodesian House and Senate was far higher than in the U.S. House or Senate. Collins further asked "Why should Rhodesia be singled out when there is not a single democracy in the whole 1970, NSC Institutional ("H”) Files, NSDM-75, box H-218, RNPL; Horne, From the Barrel of a Gun, 82; Lake, The "Tar Baby" Option, 155.

${ }^{56}$ Congressional Record, Proceedings and Debates of the 90th Congress, Second Session vol. 114, October 12, 1968; Lake, The “Tar Baby" Option, 199.

${ }^{57}$ Lake, The “Tar Baby” Option, 199-200. 
continent of Africa. If self-determination is a United Nations feature, why do we do business with Russia, Red China, Latin-American dictatorships or any other authoritarian country?"58 Racial motivations clearly played a role in Collins's rationale. In terms of authoritarianism, the congressman was clearly disinterested in the level of democracy in the newly independent states. While many new nations had descended into one-party dictatorships, others retained the vestiges of democracy. Zambia, for example, remained, at least in 1971, a multiparty democracy with a vocal opposition. Indeed, the committee was unconvinced and the measure failed. On August 5, the Senate Committee on Foreign Relations also disposed of Senate Resolution $1404 .^{59}$

The dual congressional rejection should have ended the question but Byrd proved to be a wily political operator. He was aware that the Military Procurement Act had already been passed by the House and was being considered by the Senate Armed Services Committee. Fellow conservatives Thurmond and Barry Goldwater (R-Arizona), as well as Byrd himself, were members of the committee. The senator introduced most of the language of Senate Resolution 1404 as an amendment to the act and successfully attached Section 503, or the Byrd Amendment, to the bill by a vote of $13-0 .{ }^{60}$

\footnotetext{
${ }^{58}$ Economic Sanctions against Rhodesia, Hearings before the Subcommittee on International Organizations and Movements of the Committee on Foreign Affairs, House of Representatives Ninety-Second Congress, June 17 and 22, 1971, (Washington, DC, 1971), accessed May 28, 2016, www.aluka.org/stable/10.5555/al.sff.document.uscg005?searchUri=so\%3Dps_collection_name_str\%2Basc\%26 Query\%3Dcongressional\%2Bhearings\%2Bsanctions $\% 2 \mathrm{~B}$.

${ }^{59}$ Andy DeRoche, “'You can’t fight guns with knives': National Security and Zambian responses to UDI, 19651973," in One Zambia, Many Histories, ed. Jan Bart Gewald et al. (Leiden, 2008), 90-91; DeRoche, "KK, the Godfather and the Duke," 111; Lake, The “Tar Baby” Option, 204.

${ }^{60}$ Schmidt, Foreign Intervention in Africa, 118; Thomas Borstelmann, The Cold War and the Color Line: American Race Relations in the Global Arena, (Cambridge, MA, 2003), 236-37; Lake, The “Tar Baby” Option, 204-5.
} 
Nixon, at least in private, was determined that the amendment should succeed. On September 28, he told Kissinger, “I am for the Byrd Amendment ... Don't let State pucker out of this and sink the goddamn — we want to continue to buy that chrome." Kissinger, however, urged the president to demonstrate, at least publicly, opposition to Section 503. While Kissinger was not enamored by the sanctions on Rhodesia, in his view, White House support for the Byrd Amendment could lead to excessive political costs both domestically and internationally. Kissinger felt that it was in Nixon's best interests to indicate opposition and let Congress take the heat. ${ }^{61}$

Section 503 faced significant congressional resistance from liberals and Africanists in both the House and the Senate as well as opposition from the State Department. The bill, though, now had the backing of the powerful Armed Services Committee and its influential chairman, John C. Stennis (D-Mississippi), a man whose views on racial issues aligned closely with Byrd's. It was widely believed that business interests, including Union Carbide and Foote Mineral, as well as the Rhodesian Information Office were active on Capitol Hill to press for the passage of the legislation. ${ }^{62}$

On September 23, an amendment introduced by Senator Gale McGee (D-Wyoming), Chairman of the Subcommittee on Africa, which would have deleted the Byrd Amendment was defeated on the floor. A second amendment, proposed by Senator James W. Fulbright (D-Arkansas) that would have given the president the power to refuse to implement Section

\footnotetext{
${ }^{61}$ Conversation between Nixon and Kissinger, September 28, 1971, FRUS, vol. XXVIII, doc. 57; Memorandum for the President from Henry Kissinger, Byrd Amendment threatens U.S. Adherence to UN Sanctions on Rhodesia, September 1971, NSC Country Files, Rhodesia vol. 2 (1970-1974), box 743, RNPL.

${ }^{62}$ Acting Assistant Secretary for Congressional Relations H. G. Torbert to Chairman of House Committee on Foreign Affairs Thomas E. Morgan, NSC Country Files, Rhodesia (1969-1970), box 743, RNPL; Crespino, Strom Thurmond's America, 70-71, 151; Lake, The “Tar Baby" Option, 168-69, 201, 205; Schmidt, Foreign Intervention in Africa, 118.
} 
503 if national interest or a treaty obligation required him to do was defeated on October 6.

On November 5, a committee comprised of members from both the House of Representatives and the Senate filed a report in favor of the amendment highlighting the urgent national need for Rhodesian chrome. ${ }^{63}$

Five days later, on November 10, the legislation passed the House and the following day was approved by the Senate. The New York Times blamed the racism of Byrd and other Southern senators such as Thurmond for the passage of the bill but also observed that the amendment paralleled the "Southern Strategy" adopted by the Nixon White House. ${ }^{64}$

Nixon signed the Military Procurement Act on November 17, 1971. Under Section 503, the act authorized the importation into the United States of seventy-two strategic and critical minerals from Rhodesia. The most important of these minerals was chrome. ${ }^{65}$

In late December, Secretary of State William P. Rogers urged the president to circumvent the Byrd Amendment either by using Section 5 (a) of the UN Participation Act to prohibit the import of Soviet chromite which in turn would prevent the importation of Rhodesian chrome or by removing chrome from the list of critical and strategic minerals. These proposals were strongly opposed by other government agencies. Treasury disputed the legality of using Section 5 of the UN Participation Act to prohibit importation of Soviet chromite, while Commerce feared that such a move would put at risk overall trade with the USSR. The OEP condemned the delisting of chrome as it was not only a strategic material

\footnotetext{
${ }^{63}$ Lake, The "Tar Baby" Option, 206-13.

${ }^{64}$ DeRoche, "KK, the Godfather and the Duke," 109; Lake, The "Tar Baby" Option, 206-13.

${ }^{65}$ Memorandum for the President from the Secretary of State William P. Rogers, Statement on the Provision of Military Procurement Authorization Bill Permitting the Import of Rhodesian Chrome, November 16, 1971, NSC Institutional (“H”) Files, NSSM 142, box H-188, RNPL; Memorandum for the President from Henry Kissinger, Statement To Be Made on the Signing of the Military Procurement Authorization Bill, November 16, 1971, NSC Country Files, Rhodesia vol. 2 (1970-1974), box 743, RNPL; Lake, The “Tar Baby” Option, 198.
} 
but tampering with the standards jeopardized the stockpile policy and was an evasion of congressional intent. ${ }^{66}$

Kissinger also signaled his opposition to the State Department proposals and recommended the implementation of the Byrd Amendment as Congress intended. Nixon concurred and on January 21, 1972 instructed the Treasury to draw up the necessary changes in regulations to allow the importation of Rhodesian chrome. Four days later, the Office of Foreign Assets Control at the Treasury Department issued a General License allowing the importation of Rhodesian chrome, ferrochrome as well as any other material deemed to be strategic and critical. ${ }^{67}$

The passage of the Byrd Amendment was celebrated by the Rhodesian government. The legislation would not only provide much needed foreign exchange but was a huge psychological boost to the embattled Smith regime. In December 1971, the Rhodesian Information Office held a Christmas party for which a special festive song was composed, the "503 Club Marching Song" to the tune of "O Tannenbaum.” U.S. mining interests were also

\footnotetext{
${ }^{66}$ To the President from Secretary of State William P. Rogers, Implementation of the Byrd Amendment-
} Rhodesian Chromite, December 30, 1971, NSC Country Files, Rhodesia vol. 2 (1970-1974), box 743, RNPL; Memorandum for Kissinger from Acting Secretary of Treasury Charles E. Walker, Implementation of the Byrd Amendment-Rhodesian Chromite, January 1972, NSC Country Files, Rhodesia vol. 2 (1970-1974), box 743, RNPL; Memorandum for Henry Kissinger from Office of Emergency Preparedness (hereafter OEP) Director General G. A. Lincoln, Implementation of the Byrd Amendment on Rhodesian Chromite, January 4, 1972, NSC Country Files, Rhodesia vol. 2 (1970-1974), box 743, RNPL; Memorandum for the President from Henry Kissinger, Rhodesian Chrome and the Byrd Amendment, January 17, 1972, NSC Country Files, Rhodesia vol. 2 (1970-1974), box 743, RNPL.

${ }^{67}$ Memorandum for the Secretary of State, the Secretary of the Treasury, the Secretary of Commerce and the Director of the OEP from Henry Kissinger, Implementation of the Provisions of the Military Procurement Act Relating to Rhodesian Chromite, January 21, 1972, NSC Country Files, Rhodesia vol. 2 (1970-1974), box 743, RNPL; Lake, The “Tar Baby” Option, 214. 
quick to take advantage of the new law. The first chromite shipment of 25,000 tons arrived at Burnside, Louisiana in March 1972. The consignee was the Foote Mineral Company. ${ }^{68}$

Black African countries expressed dismay at the legislation but Nixon demonstrated little concern over their protestations. Indeed, following an African inspired UN Security Council resolution that condemned the U.S. importation of chrome and other minerals, Nixon was so infuriated by the criticism that he threatened to cut off U.S. financial support to the UN. Domestically, civil rights groups, liberals, and supporters of the UN were also horrified that the United States would be doing business with the white-controlled regime, but they possessed almost no influence over the White House. ${ }^{69}$

As early as April 1972, congressional opponents of the Byrd Amendment moved swiftly to repeal the legislation but the attempt was defeated. Over the course of Nixon's remaining tenure in office, opponents of Section 503, notably Senator McGee and

\footnotetext{
${ }^{68}$ Lake, The “Tar Baby” Option, 214, 226.

${ }^{69}$ Memorandum for the President from Secretary of State William P. Rogers, Statement on the Provision of Military Procurement Authorization Bill Permitting the Import of Rhodesian Chrome, November 16, 1971, NSC Institutional (“H”) Files, NSSM 142, box H-188, RNPL; Memorandum for Henry Kissinger from Executive Secretary Theodore L. Eliot, UN Security Council Resolution on Rhodesian Sanctions 1972, NSC Country Files, Rhodesia vol. 2 (1970-1974), box 743, RNPL; Conversation among Nixon, White House Chief of Staff Haldeman and Kissinger, November 18, 1971, FRUS, vol. XXVIII, doc. 62; "Six month record: Rhodesia...ACOA fights violations of UN sanctions,” New York: American Committee on Africa, 1972 , accessed May 28, 2016, http://www.aluka.org/stable/10.5555/al.sff.document.acoa001007?searchUri=so\%3Dps_collection_name_str\%2 Basc\%26Query\%3Dsix\%2Bmonth\%2Brecord\%2Bacoa\%2Bfights\%2Bviolations\%2Bof\%2BUN\%2Bsanctions; Third Annual Report to the Congress on United States Foreign Policy, February 9, 1972, Public Papers of the Presidents of the United States, Richard Nixon, 1972, (Washington, DC, 1974), doc. 56; Lake, The "Tar Baby" Option, 219.
} 
Representative Donald Fraser (D-Minnesota), made a number of further efforts at repeal but legislation did not reach a floor vote during Nixon's time in office. ${ }^{70}$

The attempts at repeal enjoyed strong support at the State Department but the White House, while taking the public line that U.S. legislation should be in line with its international treaty obligations, also highlighted the fact that responsibility lay with Congress. In May, Presidential spokesman Jerry Warren stated, "Congress enacted the Byrd Amendment. And the Congress is now reviewing the legislation to seek conformity with the United States' international obligation. So it is up to the Congress." By the fall of 1973, the administration took a slightly stronger approach, saying that it favored repeal, but this still represented little more than lip service to ending the importation of Rhodesian chrome. ${ }^{71}$

In the words of Kissinger, such an approach "would relieve us of responsibility for the Byrd Amendment and its treaty violations, put the monkey squarely on the Senate's back

\footnotetext{
${ }^{70}$ Memorandum for the President from Henry Kissinger, The Byrd Amendment, May 10, 1972, NSC Country Files, Rhodesia vol. 2 (1970-1974), box 743, RNPL; Statement of U.S. Representative to the United Nations, Ambassador Scali, Hearings before the Subcommittee on African Affairs, Senate Committee on Foreign Relations, September 3, 1973, NSC Country Files, Rhodesia vol. 2 (1970-1974), box 743, RNPL; Statement of Assistant Secretary of State for African Affairs David P. Newsom, Hearings before the Subcommittee on African Affairs, Senate Subcommittee on Foreign Relations, September 3, 1973, NSC Country Files, Rhodesia vol. 2 (1970-1974), box 743, RNPL; Memorandum for Bud McFarlane from Hal Horan, Rhodesian Chrome: Repeal of the Byrd Amendment, December 19, 1973, NSC Country Files, Rhodesia vol. 2 (1970-1974), box 743, RNPL; Lake, The “Tar Baby” Option, 215-16, 272-75.

${ }^{71}$ Memorandum for the President from Secretary of State William P. Rogers, Legislation to Repeal the Byrd Provision on Rhodesian Sanctions, April 24, 1972, NSC Institutional (“H”) Files, NSSM 142, box H-188, RNPL; Memorandum for the President from Henry Kissinger, The Byrd Amendment, May 10, 1972, NSC Country Files, Rhodesia vol. 2 (1970-1974), box 743, RNPL; Memorandum for the President from Henry Kissinger, Repeal of the Byrd Amendment, September 1973, NSC Country Files, Rhodesia vol. 2 (1970-1974), box 743, RNPL; Lake, The “Tar Baby” Option, 220, 273.
} 
where it belongs and help defuse criticism in Africa and UN." The administration did not wish to antagonize Byrd and the chrome lobby by supporting repeal but equally wished to evade any blame for the treaty violations. This approach angered McGee who claimed that he had been misled by the White House, which had promised to call key senators to press for repeal but never did. ${ }^{72}$

On August 9, 1974, President Nixon left office rather than face impeachment. He left behind a troubled legacy and a nation in need of healing following the aftermath of Vietnam and the Watergate scandal. He also left the United States as the only nation in formal defiance of the UN sanctions on trade with Rhodesia. The Byrd Amendment remained effective legislation under U.S. law until March 1977, when under pressure from the newly elected Carter Administration, Congress finally passed a bill that circumvented Section 503 and reimposed the embargo on Rhodesian chrome, officially placing Washington back in compliance with international law. ${ }^{73}$

\section{Conclusion}

During the Nixon era, geostrategic concerns significantly impacted presidential thinking on southern Africa. Nixon and Kissinger sought to build alliances with anticommunist regional powers who would act as bulwarks against communist expansion. The White House believed that the U.S. needed to prioritize the protection of its own strategic and economic interests and not worry about the domestic agenda of its global partners. This stance was further stimulated by Nixon's lack of interest in achieving racial justice and

\footnotetext{
${ }^{72}$ Memorandum for the President from Henry A. Kissinger, The Byrd Amendment, May 10, 1972, NSC Country Files, Rhodesia vol. 2 (1970-1974), box 743, RNPL; Lake, The “Tar Baby” Option, 217.

${ }^{73}$ White House Bill Signing-H.R. 1746, An Act to Amend the United Nations Participation Act of 1945 to Halt the Importation of Rhodesian Chromium, March 18, 1977, WHCF, CO 126 1/20/77-11/30/78 through CO 1/1/78-6/30/78, box CO-50, Jimmy Carter Library.
} 
disregard of black Africa. Domestically, the racist policies of the Rhodesians appealed to many key political allies of the White House who pressed Nixon to move toward even closer ties with Salisbury.

The Nixon Administration therefore sought to develop closer relations with Salisbury along with the other members of the White Redoubt. It is worth noting, however, that Nixon was aware of the costs of becoming too friendly with Rhodesia, as it would lead to widespread international criticism, hand the moral initiative to the communists, and aggravate relations with the British. Nixon therefore chose not to normalize ties with Rhodesia or recognize the rebel regime in Salisbury but instead engage in a limited association.

When geostrategic and economic interests coincided, though, as was the case with obtaining access to Rhodesian chrome, then Nixon demonstrated no qualms in placing Washington in direct violation of UN sanctions and incurring the ire of the world community in order to achieve his objectives. For the Nixon Administration, ensuring a supply of free world chrome from an anti-communist nation trumped the domestic and international ramifications of doing business with the practitioners of white minority rule.

The historiography of U.S. foreign relations with the Third World during the 1960s and 1970s, especially the literature on Rhodesia, frequently highlights a single overriding factor as the dominating influence on American policy. When analyzing Nixon's approach to Salisbury, however, it is clear that the White House was guided by a range of dynamics including Cold War geopolitics, economics, the need for strategic raw materials, a lack of empathy for or interest in black liberation, and close domestic political ties with ardent supporters of Ian Smith who openly identified with the cause of white minority rule in Africa.

White House policy towards Salisbury clearly reveals the primary elements which shaped Nixon's attitude towards the broader White Redoubt, relations with black ruled Africa and his vision of how to shape the international periphery to best fit the interests of 
Washington. Nixon's stance on Rhodesia serves as an illuminative lens that captures the core tenets of his broader outlook on foreign policy. 